\title{
The Diversity of Labuhanbatu Community Culture in Android- Based Applications
}

\author{
Bambang Ade Sulakono ${ }^{1}$, Sumitro Sarkum ${ }^{2}$, Musthafa Haris Munandar ${ }^{3}$, Masrizal ${ }^{4}$, Deci Irmayani ${ }^{5}$ \\ 1,2,3,4 Faculty of Science and Technology, Universitas Labuhanbatu, Rantauprapat, Indonesia \\ ${ }^{5}$ Faculty of Economic and Business, Universitas Labuhanbatu, Rantauprapat, Indonesia
}

\begin{abstract}
Article Info
Article history:

Received May 12, 2020

Revised May 06, 2020

Accepted Apr 11, 2020

\section{Keywords:}

Labuhanbatu Regency, Android, Cultural Information, Descriptive

ABSTRACT

Android is an application system which has been developed by many people so that people can use the Android system in a work which can help them solve problems in their work. Android systems in smartphones can support complete facilities with Android. Labuhan Batu area is divided into three regions, because of this, knowledge is needed to explains about the culture of the people of Labuhanbatu main district separately of the people in the other districts. In this research, the author describes the research methods used in system design into two parts of method namely the research results obtained by methods using descriptive methods and the research conducted based on actual data by comparing theories and then drawing conclusions. The benefit of the authors working on this research is to make an Android-based application which eases the public to find out the information about the culture that exists in each district in Labuhanbatu Regency. Labuhanbatu Regency Cultural Information Application based on Android can be used by students and even the public, using an Android-based smartphone.
\end{abstract}

This is an open access article under the CC BY-SAlicense.

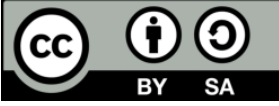

\section{Corresponding Author:}

Sumitro Sarkum,

Economic and Business Faculty

Universitas Labuhanbatu,

Sisingamangaraja 126 A, Rantauprapat, Indonesia

Email: sumitro.ulb@gmail.com

\section{INTRODUCTION (11 PT)}

The development of android technology is currently developing rapidly, the technology is not only used by users as a communication medium, but also it is used to connect with the outside world such as the internet. One of android technology is a smartphone based on Android, this Android system is a device that supports mobile systems in applications that there is a more advanced sophisticated smartphone against the current system. This is because the technology is an open source so it gets a lot of support from various technologies [1].

RantauPrapat is an area that has high city potentiality, located in the North Sumatera province, and it is consisted of several Regencies, namely Labuhan Batu Regency, Asahan Regency, and Tanjung Balai Regency. Rantauprapat is the economic center of several regencies around it certainly affects the level of population density which is increasingly increase, rapid technological 
advances and the availability of adequate public transportation facilities provided by the government to facilitate residents and the community to come to Rantauprapat district.

The Android system is an operation device which can carry out the tasks of the system. Initially, Android was developed by a small company in Silicon Valley called Android inc. Furthermore, Google took over the operating system in 2005 and declared it as an open source operating system. As a consequence, anyone may use it for free, including the source code used to compile the operating system. Information systems are a combination of work procedures, information, people, and information technology which are organized to achieve goals.

The division made Labuhanbatu Regency into three regions namely North, South and Main. Based on the data from Labuhanbatu Regency in 2019, Labuhanbatu Regency is one of the regions located in the East Coast region of North Sumatra which borders directly with Riau province. Geographically, Labuhanbatu Regency is located at 1041 '-2044' North Latitude, 99033 '-100022' East Longitude with land heights ranging from 0 to $700 \mathrm{~m}$ above the sea level. Labuhanbatu Regency area in the north is bordered by Malacca Strait and North Labuhanbatu Regency, in the south bordering with South Labuhanbatu Regency, in the west bordering with North Labuhanbatu Regency, and in the East bordering with Riau Province. Labuhanbatu Regency occupies an area of $2,561.38 \mathrm{Km}^{2}$ which consists of 9 Districts and 98 Definitive Villages. Based on this, knowledge is needed which explains about the culture of the main Labuhanbatu Regency community separately from the three districts. Based on this phenomenon it is necessary to do research about the culture of Labuhanbatu Regency which is integrated in an andorid-based application.

Responding to the things that have been described, the authors provide a new solution to speed up the process of finding information both real and non-tangible, namely by designing an information application that is based on Android-based ports controlled. This application will display information. With the design of this application, it is expected to help the public in the process of finding information on the news objects with a relatively short time and with steps which are not repeated. The following activity diagram illustrates the flow of activities in the system that is being designed:

a. From the diagram it can be seen that the activity starts with the admin, click the system menu, then the application will respond by displaying the system list menu and then the admin pressing one of the lists contained in the existing system and then the application will display the detailed information page that has been selected.

b. From the diagram it can be seen that the activity starts with the admin pressing the important number info menu, then the application will respond by displaying the important number info of the menu.

This study is expected to help the wider community to obtain information which is easily understood and interestingly studied [2],[3]. RantauPrapat is an area that has high potentiality, located in the North Sumataera region, and around it there are several Regencies, namely Labuhan Batu Regency, Asahan Regency, and Tanjung Balai Regency. Rantauprapat, the economic center of several regencies around it, certainly affects the level of population density which is increasingly increased, rapid technological advances and the availability of adequate public transportation facilities provided by the government to facilitate residents and the community to come to Rantauprapat district.

\section{RESEARCH METHOD (11 PT)}

The research method by the author uses descriptive method [6-8], which is collecting data and information about android system applications and is developed in a place in a stone harbor area, the authors take references through literature and articles obtained from internet media and perform several other activities that is:

1. Interview

Interviews are means of re-checking or proving the information or information obtained previously. The interview technique used in qualitative research is in-depth interviews. In-depth

The Diversity of Labuhanbatu Community Culture in Android-Based Applications (Bambang Ade Sulakono) 
interview is the process of obtaining information for research purposes by way of question and answer while face to face between the interviewer and the informant or interviewee, with or without using interview guides, where the interviewer and the informant are involved in social life relatively long [14-17].

2. Documents

A large number of facts and data are stored in material in the form of documentation. Most of the available data is in the form of letters, diaries, souvenirs, reports, artifacts, photographs, and so on. The main nature of this data is not limited to space and time so as to give researchers the opportunity to know things that have happened in the past. In detail, documentary materials are divided into several types, namely: autobiographies, personal letters, books or diaries, memorials, clippings, government or private documents, data on servers and flash drives, data stored on websites, and others [15].

3. Focus Group Discussion (FGD)

Focus Group Discussion (FGD) is a data collection technique that is generally carried out in qualitative research with the aim of finding the meaning of a theme according to the understanding of a group. This technique is used to uncover the meaning of a group based on the results of discussions focused on a particular problem. FGD is also intended to avoid the wrong meaning of a researcher towards the focus of the problem being studied [14].

As for the system design method, the author uses the research method development method. The method used is the software development cycle model or the SDLC (Software Development Life Cycle) waterfall model [8]. Like Figure 1 below:

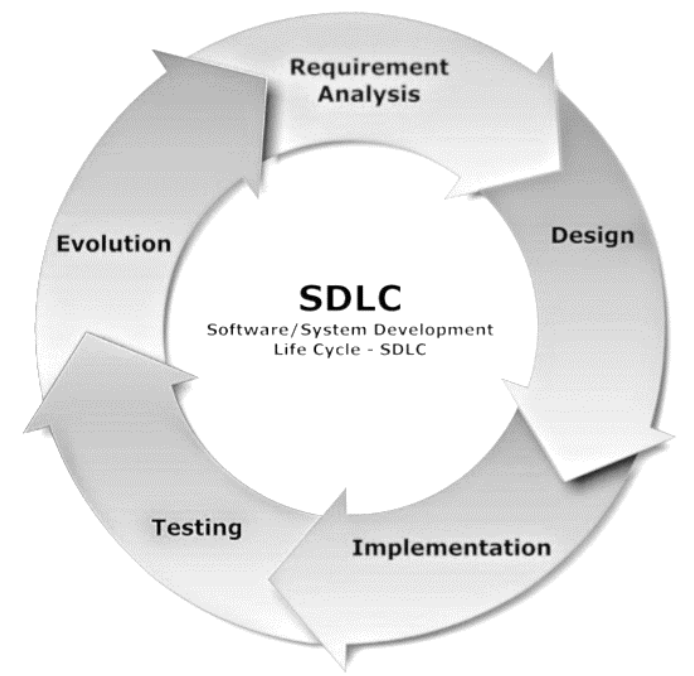

Figure 1. System Development Life Cycle (SDLC)

Some of the steps are as follows:

A. Analysis Phase.

The analysis phase is carried out by analyzing several things, while the analysis process is explained as follows:

1. Problem Analysis.

This stage explains the threat of cultural diversity in an android-based application system about what are the problems that occur in the application design process.

2. Troubleshooting.

This stage is the next stage of the problem analysis process. In this stage, solutions are outlined to overcome the problems that occur in the application design process.

3. Analysis of the Current System.

At this stage the initial process is explained about how to be able to use android by the public. This stage is described in the form of activity diagrams. 
4. System Analysis.

At this stage, it explains how a system can be proposed to solve the problem as described in the problem analysis sub-chapter. This stage is described in the form of a class diagram diagram.

5. Proposed System Modeling.

At this stage, it explains how the modelling process of news information applications can be based on Android in Rantauprapat. This modeling process describesinthe form of activity diagrams and use case diagrams.

6. Application Requirement Analysis.

At this stage, it explains what things are needed by the application such as hardware, software and other supporting devices. And alsoit explains what the functional and non-functional requirements of information applications. In this study the research method used refers to engineering methods that are included in software research that applies science into a design in order to obtain performance in accordance with specified requirements, Thedesign is a synthesis of design elements combined with scientific methods into a model that meets certain specifications. Labuhanbatu Regency uses several languages to communicate including Malay, Javanese, and Batak language. In making application tools used in the design and design of cultural diversity that exists in Labuhanbatu Regency is to use Unified Modeling Language (UML). According to Mallu (2015) Unified Modeling Language is a language that has become an industry standard for visualizing, designing and documenting software systems. Whereas Dewi et al (2014) Unfied Modeling Language is a language based on graphics or images, visualizing, specifying, building and documenting an OOP (Object Orientied Programming) software system.

Android Architecture can be depicted as shown in Figure 1 and in general Android Architecture can be explained as follows: Application and Widgets Application and Widgets are layers where applications that can be connected work together with the same system, where we usually download the application then we install and run the application. On the layer there are core applications including email clients, SMS programs, calendars, maps, browsers, contacts, and others. Almost all applications are written using the Java programming language.

\section{B. Interface Design}

The interface design image of the New Student Registration Application (Case Study: Labuhanbatu University) has 2 interfaces, namely:

\section{1) Interface User}

In Figure 2 Component Diagram user of the new student registration application explains the design of the system there is a Splash Screen MySQL database.

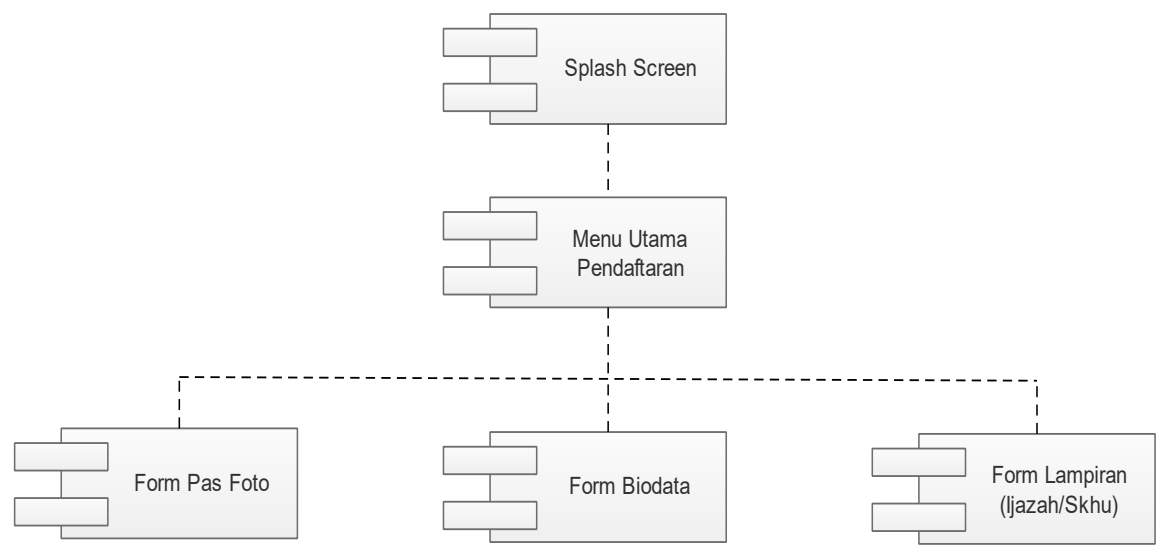

Figure 2. Component User Diagram 


\section{2) Interface Admin}

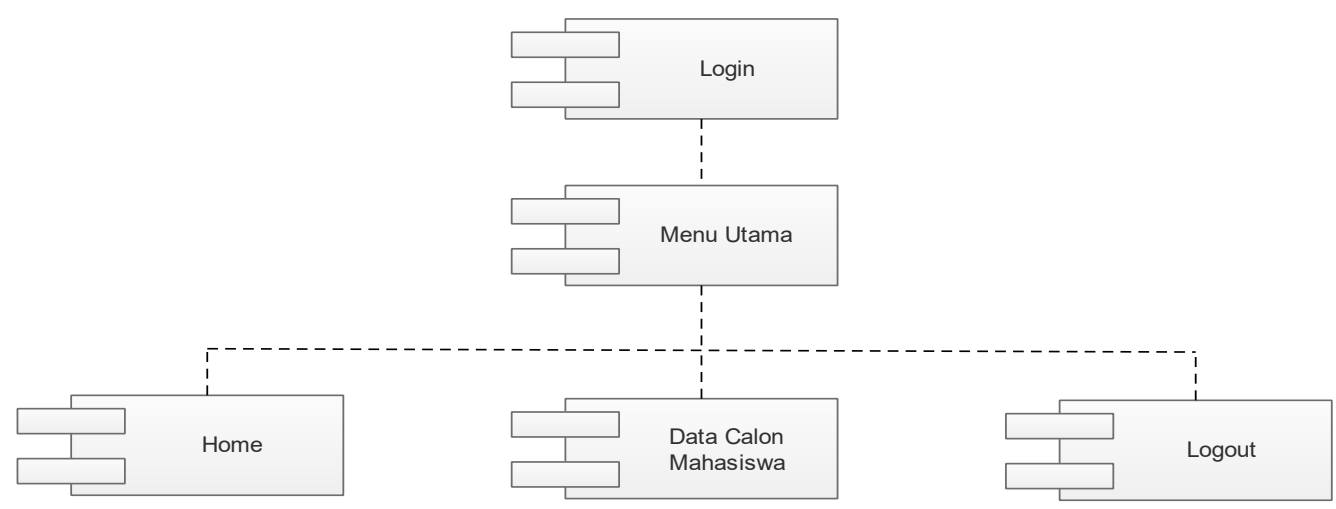

Figure 3. Admin Component Diagram

In Figure 3 Component Diagram Admin new student registration application explains the design of the system there is a Login To start the system so that confidential data is maintained, then go to the main menu home, then there is a menu of prospective student data, and also logout.

\section{RESULTS AND DISCUSSION}

In building an application which has been designed, an implementation needs to be made, because the implementation is used as a benchmark or a test and the analysis of the results of the program that has been made. Application implementation phase is the process of changing the system specification into an executable application.

At this stage will be explained the results of the part of all the functions that exist in the application such as Splahbe display, search for cultural diversity, the results of the search and display out as well as again, which will be explained in the stages below. So that users can understand in detail how to explain it.

The display Icon application of various cultures in Labuhanbatu Regency on Eclipse Emulator in Figure 4 presents an application that is in the android offline menu.

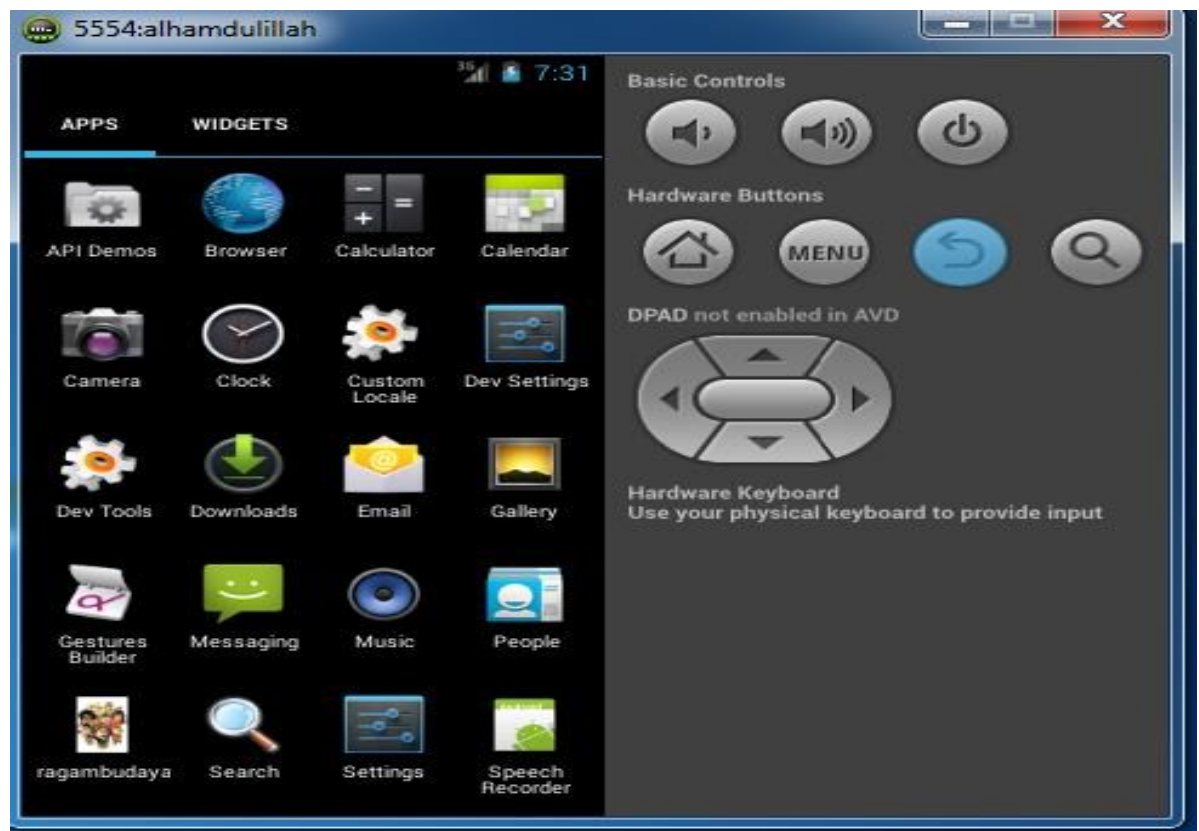

Figure 4. Appearance on the Icon Eclipse emulator of Labuhanbatu Regency Cultural Diversity Application. 
In Figure 4 is the display icon, in this display, the user can see the application icon from a variety of cultures in Labuhanbatu Regency before entering the application. Furthermore, in the Splashscreen display, the application of the cultural diversity of Labuhanbatu Regency community is contained in the Eclips emulator in Figure 4 and the display the search for diverse cultural communities in Labuhanbatu Regency. on the Eclipse emulator in Figure 5.

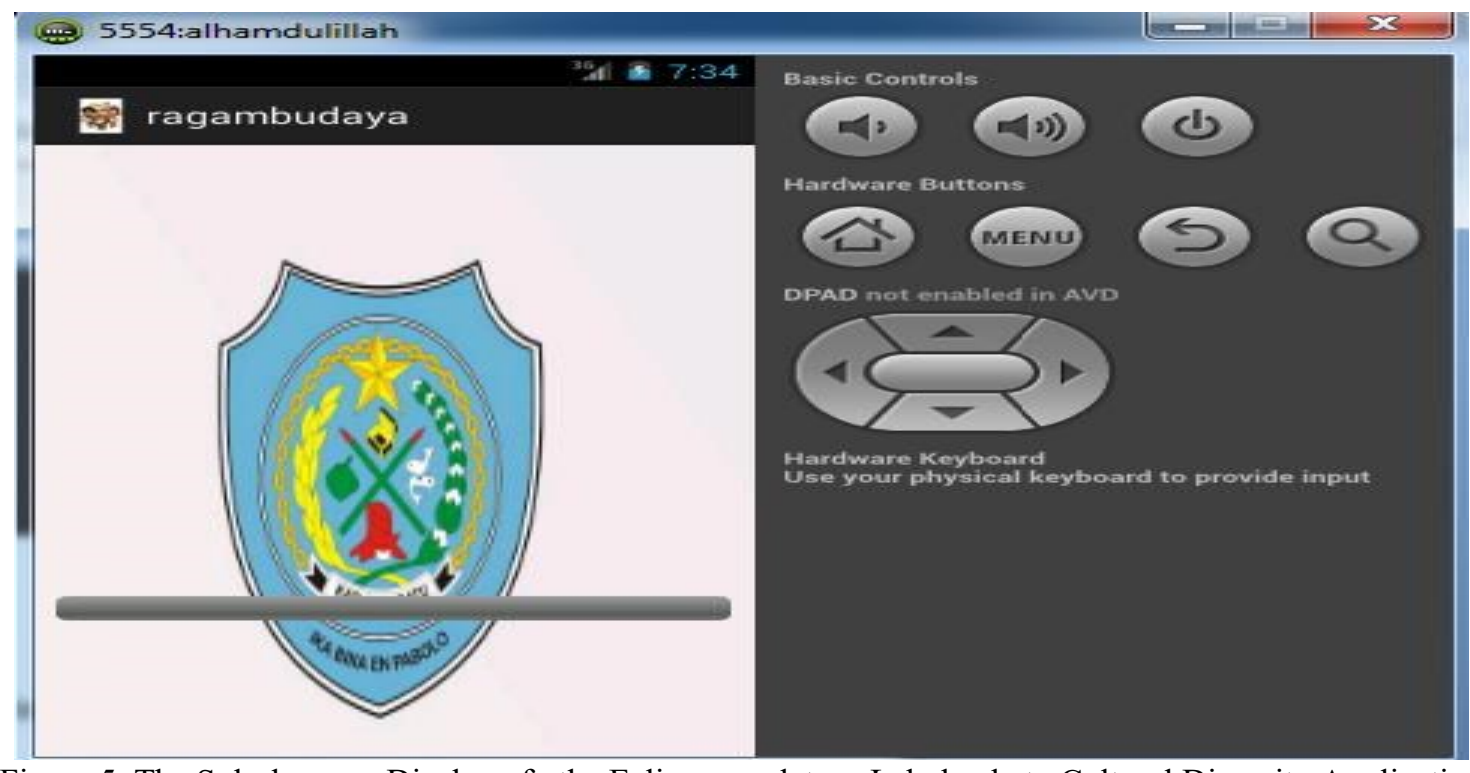

Figure 5. The Splashscreen Display of the Eclipse emulator Labuhanbatu Cultural Diversity Application

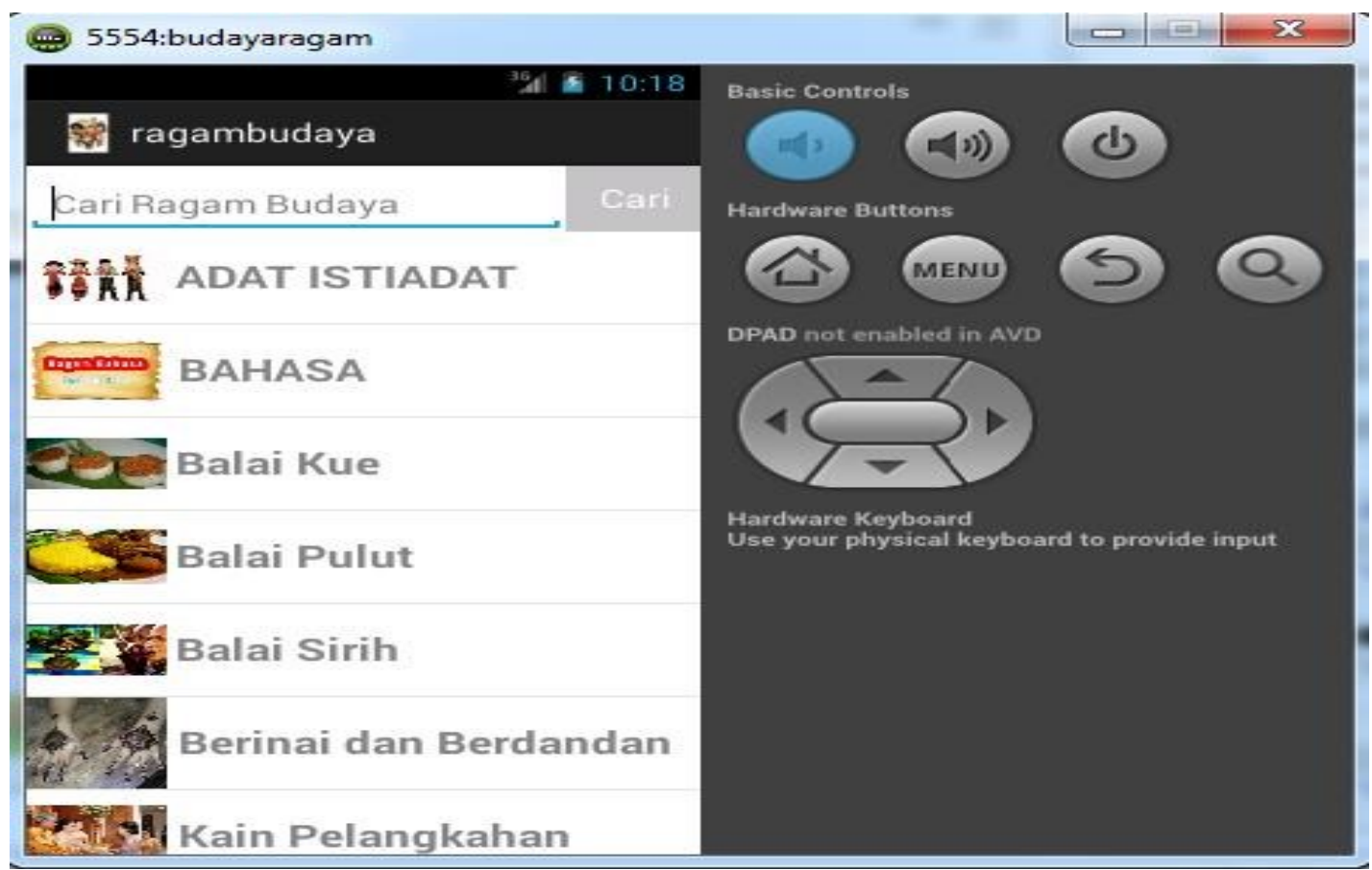

Figure 6. The Display of the Eclipse emulator of Labuhanbatu Regency Cultural Diversity Application

In Figure 6 the user can search for various languages contained in the application; for example, if you want to search an application for a variety of cultures, "Users can search for languages in a variety of cultural applications in Labuhanbatu Regency". Then, in the display of the application results of the various cultures in the Eclipse emulator set out in Figure 7. 


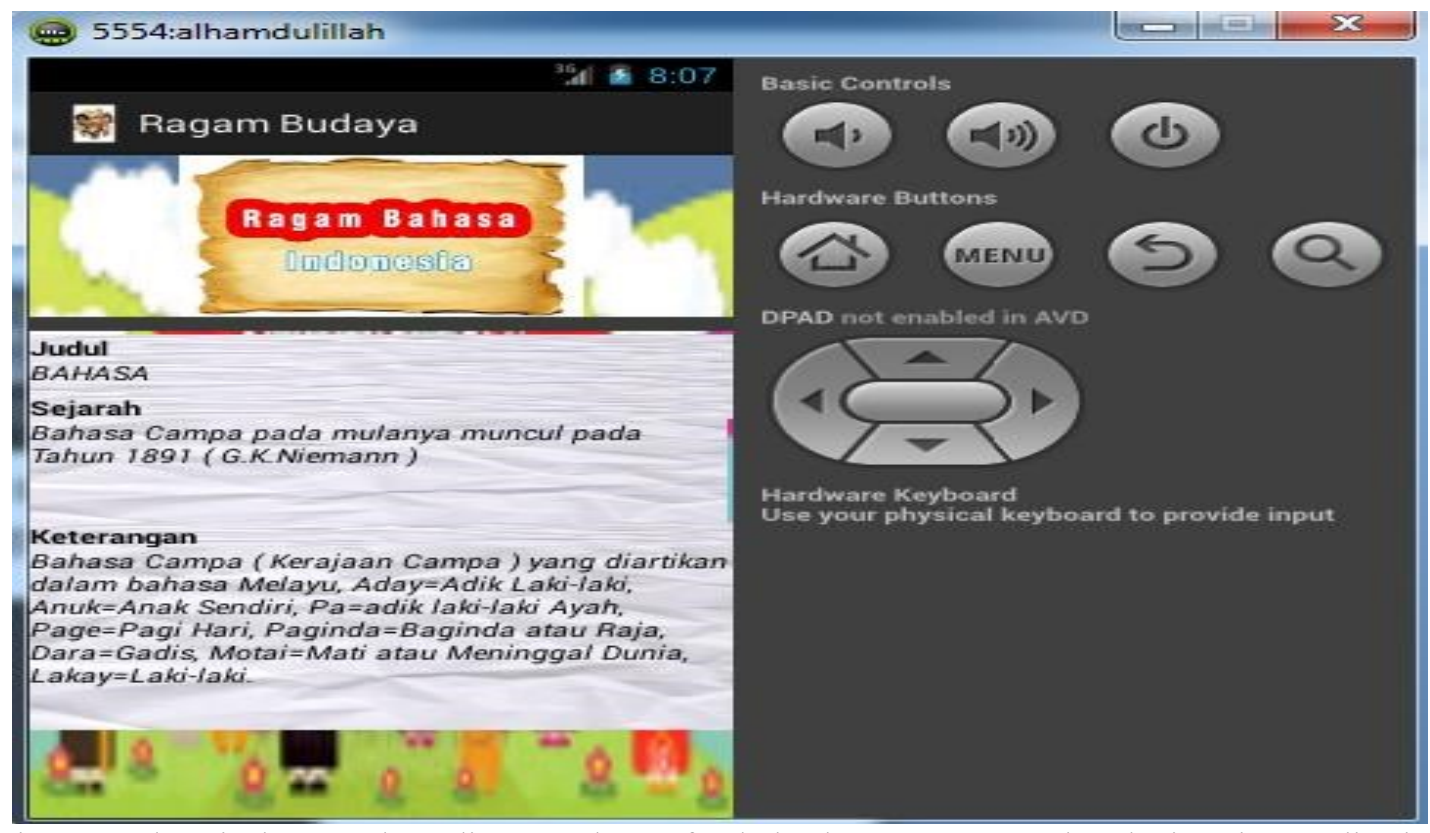

Figure 7. The Display Results Eclipse emulator of Labuhanbatu Regency Cultural Diversity Application

In the display Figure 7 is a display of results, where the user can see the search results that the user wants to know. To make it easier for users to understand the application. Repair the android system menu which is not optimal to make it easier for users when the conditions are perfect or normal. This can be seen with many devices available on Android which can help to complete the tasks that must be done by humans in daily life. day. One of them is in terms of learning where now we can carry out learning activities wherever and whenever using mobile devices such as smartphones [4],[5].

In accordance with the Android version specified is as follows:

1. Android 1.5 Cupcake. Cupcake became the first android version that was given the name It's said that this version was supposed to be version 1.2, but Google decided to make a major revision and make it version 1.5 Cupcake is a small cake baked in a cup-shaped mold.

2. Android 1.6 Donut

This version fixes several reboot errors, changes in photo and video features and better search integration. Donuts are ring-shaped comestible. Round middle hole. Donut batter is cooked by frying usually served with toping on it.

3. Android 2.0/2.1 Eclair

Eclair is a dessert that is usually a rectangular cake made with cream in the middle and a layer of chocolate on top.

4. Android 2.2 Froyo

is a dessert meal whose brand name is a product made from yogurt. Froyo stands for Frozen Yogurt, Froyo is yogurt that has undergone a cooling process, so that it looks the same as ice cream.

5. Android 2.3 Gingerbread

Gingerbread is a type of gingerbread cookie. Gingerbread is usually made at the end of year holidays in America. Usually these dry snacks are shaped like a human body.

The Android journey began in October 2003 when 4 IT experts, Andi Rubin, Rich Minner, Nick Sears and Chris White founded Android.Inc, in California US. Android's vision to realize mobile devices that are more sensitive and understand their owners, then attracts Google's giant virtual world. Google then acquired Android in August 2005. The Android operating system was formed based on the Linux platform which is an open source, in line with Linux, Android is also an Open Source. With the big-name Google and the concept of open source on the Android OS, it doesn't 
take long for android to compete and set aside other Mobile OS like Symbian, Windows Mobile, Blackberry and iOS. Now who does not know Android, which has been transformed into the ruler of the Operating System for Smartphone Maps [5].

\section{CONCLUSION (11 PT)}

Based on the implementation of the Labuhanbatu Regency Cultural Diversity Application, it can be concluded that the Android-based Labuhanbatu Regency Cultural Diversity application can be utilized by students and students even the general public, who use an Android-based smartphone. In making Android-based cultural learning applications only take a few common examples of culture in Indonesia.

Making Labuhanbatu Regency Cultural Diversity Applications by using Eclipse and using SQLite database is easier in terms of design and for the final results and is easier for users to understand because it uses an Android-based Java programming language. The purpose of this research is to build an Android-based application. Which later is expected to be useful to map the existing educational facilities in the city of Palembang. The methodology used is the author designs the application, then tests the application. Based on the implementation, it can be concluded that the application can help users in searching.

\section{REFERENCES}

[1] J. Lombardo, R. Rogers, Z. Mednicks and B. Meike, Android application development. Sebastopol: O'Reilly, 2009.

[2] S. Sari, R. Anjani, I. Farida and M. Ramdhani, "Using Android-Based Educational Game for Learning Colloid Material", Journal of Physics: Conference Series, vol. 895, p. 012012, 2017. Available: 10.1088/1742-6596/895/1/012012.

[3] P. S. Kochhar, F. Thung, N. Nagappan, T. Zimmermann, and D. Lo, "Understanding the Test Automation Culture of App Developers," 2015 IEEE 8th International Conference on Software Testing, Verification and Validation (ICST), 2015.

[4] Murtiwiyati and G. Lauren, "Rancang Bangun Aplikasi Pembelajaran Budaya Indonesia Untuk Anak Sekolah Dasar berbasis Android," J. Ilm., vol. 12, p. 2,3, 2013.

[5] J. K. Lippincott, "A mobile future for academic libraries," Reference Services Review, vol. 38, no. 2, pp. 205-213, 2010.

[6] E. A. Putra, "Anak Berkesulitan Belajar di Sekolah Dasar Se-Kelurahan Kalumbuk Padang," J. Ilm. Pendidik. Khusus, vol. 1, no. 3, pp. 71-76, 2015.

[7] D. Roessner, "Quantitative and qualitative methods and measures in the evaluation of research," Research Evaluation, vol. 9, no. 2, pp. 125-132, Jan. 2000.

[8] D. Sousa, "Validation in Qualitative Research: General Aspects and Specificities of the Descriptive Phenomenological Method," Qualitative Research in Psychology, vol. 11, no. 2, pp. 211-227, Jun. 2014.

[9] M. dkk Linarwati, "Studi Deskriptif Pelatihan Dan Pengembangan Sumberdaya Manusia Serta Penggunaan Metode Behavioral Event Interview Dalam Merekrut Karyawan Baru Di Bank Mega Cabang Kudus," J. Manage., vol. 2, no. 2, pp. 1-8, 2016, doi: 10.1016/j.bpc.2013.02.004.

[10] S. Q. Qu and J. Dumay, "The qualitative research interview," Qualitative Research in Accounting \& Management, vol. 8, no. 3, pp. 238-264, 2011.

[11] M. I. Aan Prabowo, Heriyanto, S.Sos., "Analisis Pemanfaatan Buku Elektronik (E-Book) Oleh Pemustaka di Perpustakaan SMA Negeri 1 Semarang," J. Ilmu Perpust., vol. 2, no. 2, pp. 1-9, 2013.

[12] W. S. Dharmawan, D. Purwaningtias, and D. Risdiansyah, "Penerapan Metode SDLC Waterfall Dalam Perancangan Sistem Informasi Administrasi Keuangan Berbasis Desktop," J. Khatulistiwa Inform., vol. 6, no. 2, pp. 159-167, 2018, doi: 10.31294/khatulistiwa.v6i2.160.

[13] B. ., R. M. R. A, and S. B. C, "A Systematic Survey on Waterfall Vs. Agile Vs. Lean Process Paradigms," i-managers Journal on Software Engineering, vol. 9, no. 3, pp. 34-59, 2015.

[14] G. Hamdi and Krisnawati, "Membangun Aplikasi Berbasis Android 'Pembelajaran Psikotes' Menggunakan App Inventor," J. DASI Vol. 12 No. 4 DESEMBER 2011, vol. 12, no. 4, p. 28, 2011. 
[15] H. N. Lengkong, A. A. E. Sinsuw, and A. S. M. Lumenta, "Perancangan Penunjuk Rute Pada Kendaraan Pribadi Menggunakan Aplikasi Mobile GIS Berbasis Android Yang Terintegrasi Pada Google Maps,” E-Journal Tek. Elektro Dan Komput., vol. 4, no. 2, pp. 18-25, 2015.

[16] J. H. Frey, "Questionnaire design, interviewing and attitude measurement," Evaluation and Program Planning, vol. 17, no. 1, pp. 33-34, 1994.

[17] B. Haworth, J. Whittaker, and E. Bruce, "Assessing the application and value of participatory mapping for community bushfire preparation," Applied Geography, vol. 76, pp. 115-127, 2016. 